\title{
Early, biomarker-guided steroid dosing in COVID-19 Pneumonia: a pilot randomized controlled trial
}

\author{
Yewande E. Odeyemi ${ }^{1}$, Sarah J. Chalmers ${ }^{1}$, Erin F. Barreto ${ }^{2}$, Jacob C. Jentzer ${ }^{3}$, Ognjen Gajic ${ }^{1 *}$ (D) and \\ Hemang Yadav ${ }^{1}$
}

Abstract
ClinicalTrials.gov identifier (NCT number): NCT03852537, Registered February 25, 2019.

Keywords: C-reactive protein, Corticosteroids, Coronavirus disease 2019

\begin{abstract}
Although corticosteroid administration has been associated with improved outcomes in severe COVID-19 pneumonia, their ideal use remains undefined with a "one size fits all" approach used, irrespective of the individual inflammatory response [1]. Recent studies have highlighted distinct COVID-19 inflammatory phenotypes with differential responses to corticosteroids [2]. Our goal was to assess the feasibility and safety of an individualized, biomarker-guided corticosteroid dosing approach utilizing C-reactive protein (CRP) in patients with pneumonia and acute hypoxemic respiratory failure (AHRF). With the COVID-19 outbreak, a separate COVID-19 trial arm was created, which we report here.

This was a single-center, pilot randomized controlled trial conducted in Mayo Clinic, Rochester, Minnesota from March 2020 through November 2020. Patients with COVID-19 pneumonia and AHRF were randomized to biomarker-guided corticosteroid dosing versus usual care. In the intervention arm, corticosteroid dosing and duration was adjusted to daily CRP level. The dosing algorithm was extrapolated from prior retrospective data [3]. Corticosteroid use and dosing in the usual care arm
\end{abstract}

*Correspondence: Gajic.ognjen@mayo.edu

${ }^{1}$ Division of Pulmonary and Critical Care Medicine, Mayo Clinic, 200 First Street SW, Rochester, MN 55905, USA

Full list of author information is available at the end of the article was determined by the treating physician. Of note, there was a practice change related to corticosteroid administration during the enrollment period following the publication of the RECOVERY trial [4]. All patients had CRP and Troponin measurements on the day of enrollment and then daily for 5 days. The primary outcome was the feasibility of the trial protocol. Secondary outcomes included cumulative corticosteroid exposure, hospitalfree days, oxygen-free days, and evidence of cardiac injury (troponin elevation, echocardiographic evidence of new cardiac dysfunction).

Of 41 patients enrolled, 19 were randomized to the intervention arm and 22 to the usual care arm. No significant differences were observed between groups with regards to age, sex, comorbidities, and oxygen delivery devices (see Table 1). Study treatment protocol was followed in 18 (95\%) patients in the intervention arm. In the intention to treat analysis the intervention arm had more oxygen-free days $(23.5(21,25)$ versus $21(17,25)$, $p=0.033)$ and hospital-free days $(21(18,22)$ versus 18.5 $(15,21), p=0.05)$ than the usual care arm. Daily distribution of CRP in both arms revealed significantly lower CRP levels on day 3 in the intervention arm compared to the usual care arm (see Fig. 1).

Seventeen (90\%) patients in the intervention arm received corticosteroids and 2 patients (due to low CRP levels) did not base on the CRP guided protocol. 11 original author(s) and the source, provide a link to the Creative Commons licence, and indicate if changes were made. The images or other third party material in this article are included in the article's Creative Commons licence, unless indicated otherwise in a credit line to the material. If material is not included in the article's Creative Commons licence and your intended use is not permitted by statutory regulation or exceeds the permitted use, you will need to obtain permission directly from the copyright holder. To view a copy of this licence, visit http://creativecommons.org/licenses/by/4.0/. The Creative Commons Public Domain Dedication waiver (http://creativeco mmons.org/publicdomain/zero/1.0/) applies to the data made available in this article, unless otherwise stated in a credit line to the data. 
Table 1 Baseline patient demographics and clinical characteristics

\begin{tabular}{|c|c|c|}
\hline Characteristic & Usual Care $(\mathrm{N}=22)$ & Intervention $(\mathrm{N}=19)$ \\
\hline \multicolumn{3}{|l|}{ Sex, $n(\%)$} \\
\hline Female & $9(41 \%)$ & $8(42 \%)$ \\
\hline Male & $13(59 \%)$ & $11(58 \%)$ \\
\hline Age (years), median (Q1, Q3) & $60.0(50.0,66.0)$ & $59.0(51.0,81.0)$ \\
\hline \multicolumn{3}{|l|}{ Race, $n(\%)$} \\
\hline Asian & $2(9 \%)$ & $0(0 \%)$ \\
\hline Black or African American & $0(0 \%)$ & $2(10.5 \%)$ \\
\hline Unknown/Not Reported & $3(14 \%)$ & $2(10.5 \%)$ \\
\hline White & 17 (77\%) & $15(79 \%)$ \\
\hline BMI $\left(\mathrm{kg} / \mathrm{m}^{2}\right)$, median $(\mathrm{Q} 1, \mathrm{Q} 3)$ & $32.3(28.5,39.1)$ & $30.8(27.2,39.9)$ \\
\hline Saturation/FIO2 Ratio & $332(267.4,430.5)$ & $339(250,423)$ \\
\hline \multicolumn{3}{|l|}{ Oxygen delivery at randomization, $n$ (\%) } \\
\hline HFNC & $7(32 \%)$ & $3(16 \%)$ \\
\hline Mechanical ventilation & $1(4 \%)$ & $1(5 \%)$ \\
\hline Nasal Cannula & $14(64 \%)$ & $11(58 \%)$ \\
\hline Room air & $0(0 \%)$ & $4(21 \%)$ \\
\hline COPD, $n(\%)$ & $0(0 \%)$ & $0(0 \%)$ \\
\hline Admitted to ICU at randomization, $n(\%)$ & $10(45 \%)$ & $4(21 \%)$ \\
\hline Sepsis, $n(\%)$ & $0(0 \%)$ & $0(0 \%)$ \\
\hline Diabetes, $n(\%)$ & $5(23 \%)$ & $4(21 \%)$ \\
\hline Asthma, $n(\%)$ & $4(18 \%)$ & $1(5 \%)$ \\
\hline Home oxygen use, $n(\%)$ & $0(0 \%)$ & $0(0 \%)$ \\
\hline Dementia, $n(\%)$ & $0(0 \%)$ & $1(5 \%)$ \\
\hline
\end{tabular}

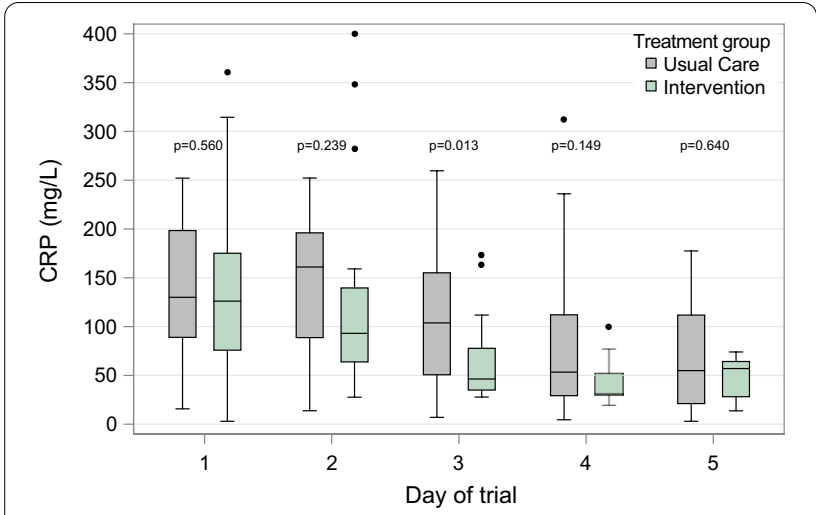

Fig. 1 Daily C-reactive protein distribution by arm. CRP: C-reactive Protein

(50\%) patients in the usual care arm received corticosteroids. Steroid use was rare prior to the publication of RECOVERY trial in June 2020. After June 2020, patients in the usual care arm typically received fixed-dose dexamethasone.

When the analysis was restricted to patients that received steroids in both groups, the intervention arm $(\mathrm{n}=17)$ had less cumulative steroid exposure [median
$122(102.0,160.0$ ) versus $256(128,320) \mathrm{mg}, p=0.005]$, more oxygen-free days $[23(20,25)$ versus $17(8,22)$, $p=0.032]$ and no difference in hospital-free days [21 (18, 22) versus $17(7,21), p=0.06]$ than the usual care arm $(\mathrm{n}=11)$.

The results of this single-center pilot randomized controlled clinical trial show that an individualized biomarker-guided corticosteroid dosing approach in pneumonia using CRP is feasible and safe with high adherence to the study protocol. Although not powered to detect differences in patient-centered outcomes, the individualized CRP-guided corticosteroid dosing approach was associated with increased oxygen-free days, hospital-free days, and a lower corticosteroid cumulative exposure in the intervention arm. This is the first study evaluating an individualized biomarker-guided strategy to inform corticosteroid dosing in COVID-19 pneumonia. The protocol outlined can provide a more precise strategy of adjunct drug delivery than the current one-size-fits-all approach. A larger, multicenter clinical trial is needed to determine the efficacy and safety of this approach.

\section{Abbreviations}

COVID-19: Coronavirus 2019; CRP: C-reactive protein. 


\section{Authors' contributions}

$\mathrm{YO}, \mathrm{SC}, \mathrm{EB}, \mathrm{OG}$, and $\mathrm{HY}$ contributed to the initial study concept and design. $\mathrm{YO}$ and $\mathrm{HY}$ significantly contributed to subject recruitment and the data acquisition. YO, OG and $\mathrm{HY}$ contributed to analysis. YO, SC, EB, JJ, OG, and $\mathrm{HY}$ contributed to the writing of the letter, provided intellectual contributions to the content, and made critical revisions; All authors read and approved the final manuscript.

\section{Funding}

This work was supported by: The American Heart Association COVID-19 Rapid Response Grant. The Mayo Clinic Critical Care Independent Multidisciplinary Program (IMP) Research Grant (Institutional Departmental grant). CTSA Grant Number UL1 TR002377 from the National Center for Advancing Translational Science (NCATS). Its contents are solely the responsibility of the authors and do not necessarily represent the official views of the NIH. The Office of Research and Diversity Inclusion Research Career Support and Advancement Award (recipient: Yewande Odeyemi). National Heart, Lung, and Blood Institute grant number K23HL151671.

\section{Availability of data and materials}

The datasets generated and/or analyzed during the current study are available on ClinicalTrials.gov identifier (NCT number): NCT03852537 https://clinicaltr ials.gov/show/NCT03852537

\section{Declarations}

\section{Ethics approval and consent to participate}

This study was approved by the Mayo Clinic Institutional Review Board (IRB number: 18-010925) prior to its initiation. Written informed consent was obtained from all the patients or from a legal representative.

\section{Consent for publication}

Not applicable.

\section{Competing interests}

The authors declare that they have no competing interests.

\section{Author details}

'Division of Pulmonary and Critical Care Medicine, Mayo Clinic, 200 First Street SW, Rochester, MN 55905, USA. ${ }^{2}$ Department of Pharmacy, Mayo Clinic, Rochester, MN 55905, USA. ${ }^{3}$ Department of Cardiovascular Medicine, Mayo Clinic, Rochester, MN 55905, USA.

Received: 29 November 2021 Accepted: 19 December 2021

Published online: 04 January 2022

\section{References}

1. COVID-19 Treatment Guidelines-NIH. (COVID-19 Treatment Guidelines Panel. Coronavirus Disease 2019 (COVID-19) Treatment Guidelines. National Institutes of Health. Available at https://www.covid19treatmen tguidelines.nih.gov/. Accessed [11/11/21])

2. Sinha $P$, Furfaro $D$, Cummings $M J$, et al. Latent class analysis reveals COVID-19-related acute respiratory distress syndrome subgroups with differential responses to corticosteroids. Am J Respir Crit Care Med. 2021;204(11):1274-85. https://doi.org/10.1164/rccm.202105-1302OC.

3. Torres A, Sibila O, Ferrer M, et al. Effect of corticosteroids on treatment failure among hospitalized patients with severe community-acquired pneumonia and high inflammatory response: a randomized clinical trial. JAMA. 2015;313(7):677-86. https://doi.org/10.1001/jama.2015.88.

4. Dexamethasone in Hospitalized Patients with Covid-19-Preliminary Report. New England Journal of Medicine 2020. https://doi.org/10.1056/ NEJMoa2021436.

\section{Publisher's Note}

Springer Nature remains neutral with regard to jurisdictional claims in published maps and institutional affiliations.

Ready to submit your research? Choose BMC and benefit from:

- fast, convenient online submission

- thorough peer review by experienced researchers in your field

- rapid publication on acceptance

- support for research data, including large and complex data types

- gold Open Access which fosters wider collaboration and increased citations

- maximum visibility for your research: over $100 \mathrm{M}$ website views per year

At BMC, research is always in progress.

Learn more biomedcentral.com/submissions 